\title{
Component composition of radish root essential oil
}

\section{Galina Selyutina, Oksana Gapontseva}

\section{Kharkiv State University of Food Technology and Trade, Kharkiv, Ukraine}

Keywords:

Radish

Essential oils

Volatile substances

Odour

\section{Article history:}

Received 09.10.2016

Received in revised form 11.10 .2016

Accepted 27.12.2016

\section{Corresponding author:}

Galina Selyutina

E-mail:

sinps@meta.ua

\section{Abstract}

Introduction. Radish roots contain in their composition essential oils, which are in the form of glucosides and cause its specific odor and taste. The content of volatile substances is an important indicator for determining of root consumer characteristics.

Materials and methods. Radish roots of varieties Black radish, White radish, Marushka, Lebidka, Troyandova, Sertse drakona, Margelan radish and daikon were investigated. The identification and quantitative composition of the radish essential oils were determined by chromatography-mass spectrometry method.

Results and discussion. Complex volatile compositions isolated from radish roots of various economic and botanical varieties are, mainly, represented by the following compounds: hydrocarbons, sulfurcontaining substances, organic acids, aldehydes, esters, ketones, terpenes, alcohols and arenas, total mass fraction of which is in the range of $23,69 \mathrm{mg} / \mathrm{kg}$ (Lebidka) to $1605,94 \mathrm{mg} / \mathrm{kg}$ (White radish). From 26 to 40 chemicals compounds are found, most of which are specific to each analyzing variety, but 14 substances are common to all the varieties of radish: nonanal, pentadekanal, dioktylftalat, dyizobutylftalat squalene, linoleic acid, linolenic acid, oleic acid, stearic acid, trycosane, tetracosane, pentacosane, hexacosane and heptacosane.

Diverse component composition of radish volatile substances determines specificity and intensity of its flavor, has a significant impact on taste properties and makes antibacterial activity against gram-positive and gram-negative microorganisms.

Conclusions. The complex research of qualitative and quantitative composition of radish root volatile substances in varietal perspective was conducted for the first time.

DOI: $10.24263 / 2304-$ 


\section{Introduction}

Radish (Raphanus) belongs to the family cruciferous (cabbage) of one- or two-year plants, this family has from 6 to 8 species and has geographical varieties, which are European (radish) is grown in many countries of the Northern Hemisphere and Asian (Chinese - lobo, Japanese - daikon) is distributed mainly in Asia.

It is known from the literature $[1,2]$ that the radish contains a number of essential oils, which are in the form of glucosides and determine its specific smell and taste. Their content in different varieties ranges from 8,4 to $50 \mathrm{mg}$ per $100 \mathrm{~g}$ of raw material, black radish contains them from 8,4 to $21,4 \mathrm{mg}$ per $100 \mathrm{~g}$. So, F.V. Tserevytynov's researchers show that the essential oil of radish (sulforafen) consists of liquid and crystalline parts. The crystalline part contains lactone rafanolid $\left(\mathrm{C}_{29} \mathrm{H}_{55} \mathrm{O}_{4}\right)$ with melting temperature of $62{ }^{\circ} \mathrm{C}$. In addition, the volatile oils of the radish contain allyl mustard oil, methylmercaptan (which causes smell), glycoside synalbin [3]. The crystalline part consists mainly of lactoneurafapolid which precipitates in the form of crystals.

The radish is used as a remedy that increases the formation and secretion of bile from the gallbladder to the intestine due to the content in its roots of rafanous and sulfurous oils, and it is extremely important in the treatment of cholecystitis and for cholelithiasis prevention [4].

The substance trans-4-methylthio-3-butenyl-isothiocyanate causes spicy taste and has antimicrobial activity against a number of fungi and bacteria in the range of 50 to 400 $\mathrm{mg} / \mathrm{ml}$, while the yeast is more resistant and is not affected by this substance. Sis-isomeryd in ratio of Trans-cis $4: 1$ is also contained [5].

The content of essential oils defines the consumable characteristics of vegetable raw material as they participate in the formation of flavor, thereby provide consumers with an idea about food quality and whet appetite.

It should be noted that the complex studies of component and quantitative compositions of volatile substances in terms of varietal perspective were not conducted. These studies are of great practical importance, since volatile components are widely used in medicine as antiseptic preparations and remedies for aromatherapy, aromatic substances are used in food, perfume, cosmetics production.

With taking into account the specific organoleptic properties of radish, the aim of our study is research the complex of different varieties of radish volatiles, it allows providing comprehensive description of the root, which later will became the basis for the distribution of varieties according to tendencies of use (for industrial processing or for health care purposes).

\section{Materials and methods}

Study of quantitative and qualitative composition of volatile fraction of radish root is carried out with use Agilent Technologies 6890 chromatograph with mass spectrometric detector is 5973, column is capillary DB-5 with length of 30 meters and inner diameter of $0.25 \mathrm{~mm}$, according to the method of L.B. Chernohorod and B.A. Vynohradova. [6,7] The sample (5 $\mathrm{g}$ of radish root) is put in vial of $20 \mathrm{ml}$ and internal standard is added. Tridecane is used as internal standard, at $50 \mathrm{mg}$ per sample, with following calculation of the resulting concentration of internal standard, which is then used for calculation of the substance 
amount. $10 \mathrm{ml}$ of distilled water is added to the sample and volatiles of the sample are distilled off with steam for 2 hours with use of the air-cooled inverse refrigerator. During the distillation volatiles are adsorbed on the inner surface of inverse refrigerator. Adsorbed substances after cooling of the system are washed off with slow addition of $3 \mathrm{ml}$ of pure pentane in dry vial of $10 \mathrm{ml}$. Washout is concentrated by blowing $(100 \mathrm{ml} / \mathrm{min})$ of pure nitrogen to extract residual volume of $10 \mathrm{ml}$, which is fully selected by chromatographic syringe. Further concentration of the sample is carried in the syringe to the volume of $2 \mathrm{ml}$.

Putting the sample in chromatographic column is carried out in splitless mode (without flow division) that allows putting the sample without losing for division and significantly (in 10-20 times) increasing sensitivity of the chromatography method. The speed of the sample putting is $1,2 \mathrm{ml} / \mathrm{min}$ during 0,2 minutes. The speed of gas carrier (helium) is 1,2 $\mathrm{ml} / \mathrm{min}$. The temperature of the sample putting heater is $250{ }^{\circ} \mathrm{C}$. Thermostat temperature is programmed from 50 to 320 degrees at speed of $4 \% \mathrm{~min}$.

The library of mass spectra NIST05 and WILEY 2007 with total number of spectra more than 470000, combined with programs for identifying AMDIS and NIST is used for identifying the components.

The method of internal standard is used for quantitative calculations. Calculation of components content $(\mathrm{mg} / \mathrm{kg})$ is carried out by the formula:

$$
\mathrm{C}=\mathrm{K}_{1} \cdot \mathrm{K}_{2}
$$

where: $K_{1}=P_{1} / P_{2}\left(P_{1}\right.$ - peak area of the analyzing substance, $P_{2}$ - standard peak area); $K_{2}=$ $50 / \mathrm{M}(50$ - weight of internal standard $(\mathrm{mg})$ which is added to the sample, $\mathrm{M}$ - mass of the sample (g) [8].

\section{Results and discussion}

The identification of compounds was carried out by comparing the mass spectra of the chromatographic peak with the mass spectra of reference compounds; with high probability they were identified by the identified program on the array of spectra database (Figures 1 8).

Comparison component composition of volatile substances of different varieties of radish showed (Table 1) that their composition in the sample Black radish were represented with 35 components ( 2 of them were not identified), White radish - 31 (1 was not identified), Marushka - 27, Lebidka - 38 ( 2 were not identified), Troyandova - 40 (1 was not identified), Sertse drakona - 36 (1 was not identified), Margelan radish - 26 (1 was not identified), daikon - 39 ( 2 were not identified). Complex volatile compositions isolated from radish are represented with chemical compounds of such groups: carbonyl (aldehydes, ketones), alcohols, organic acids, esters, terpenes, hydrocarbons, sulfur and aromatic compounds. 


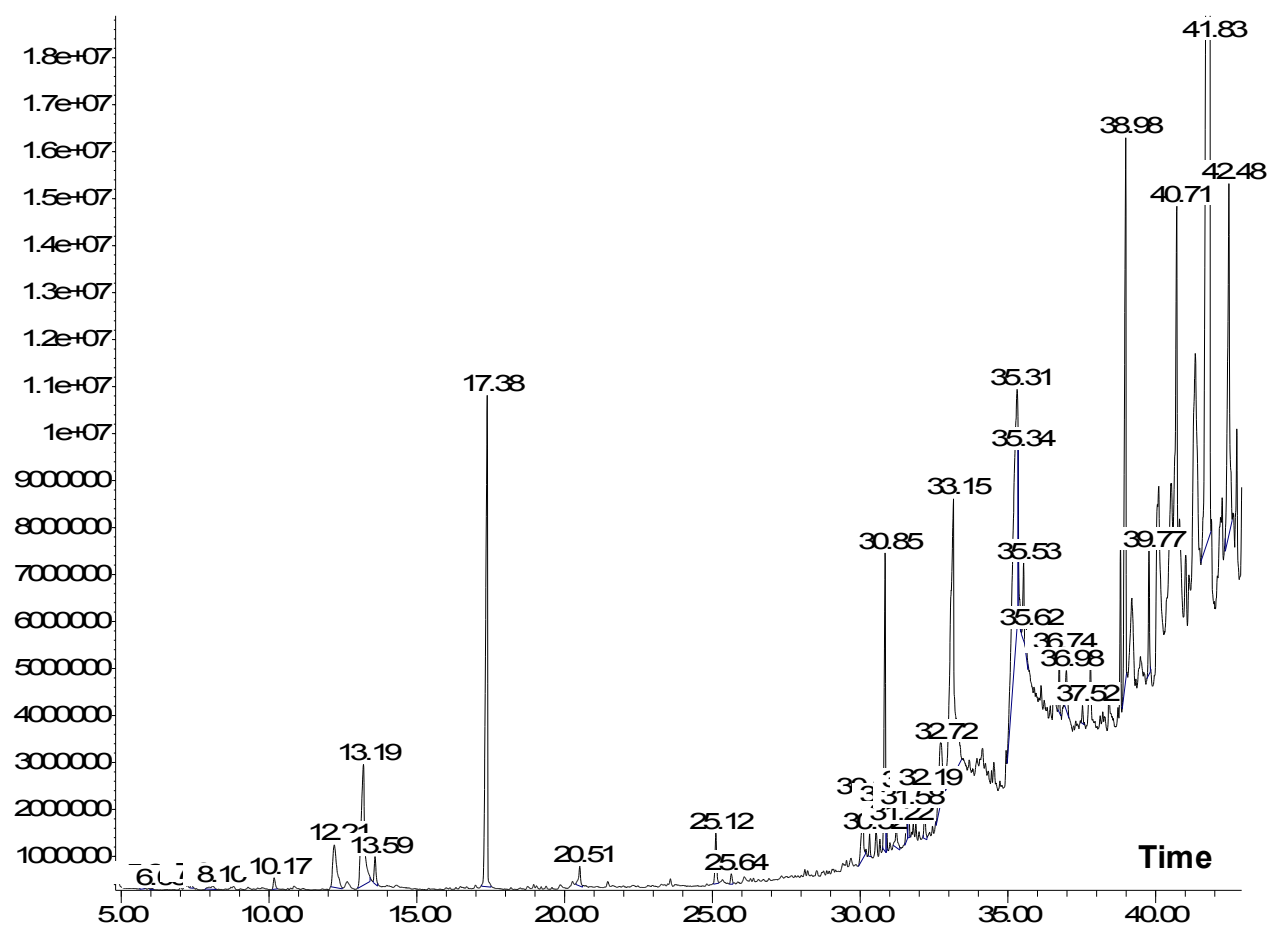

Figure 1. The composition of volatile components of radish Black

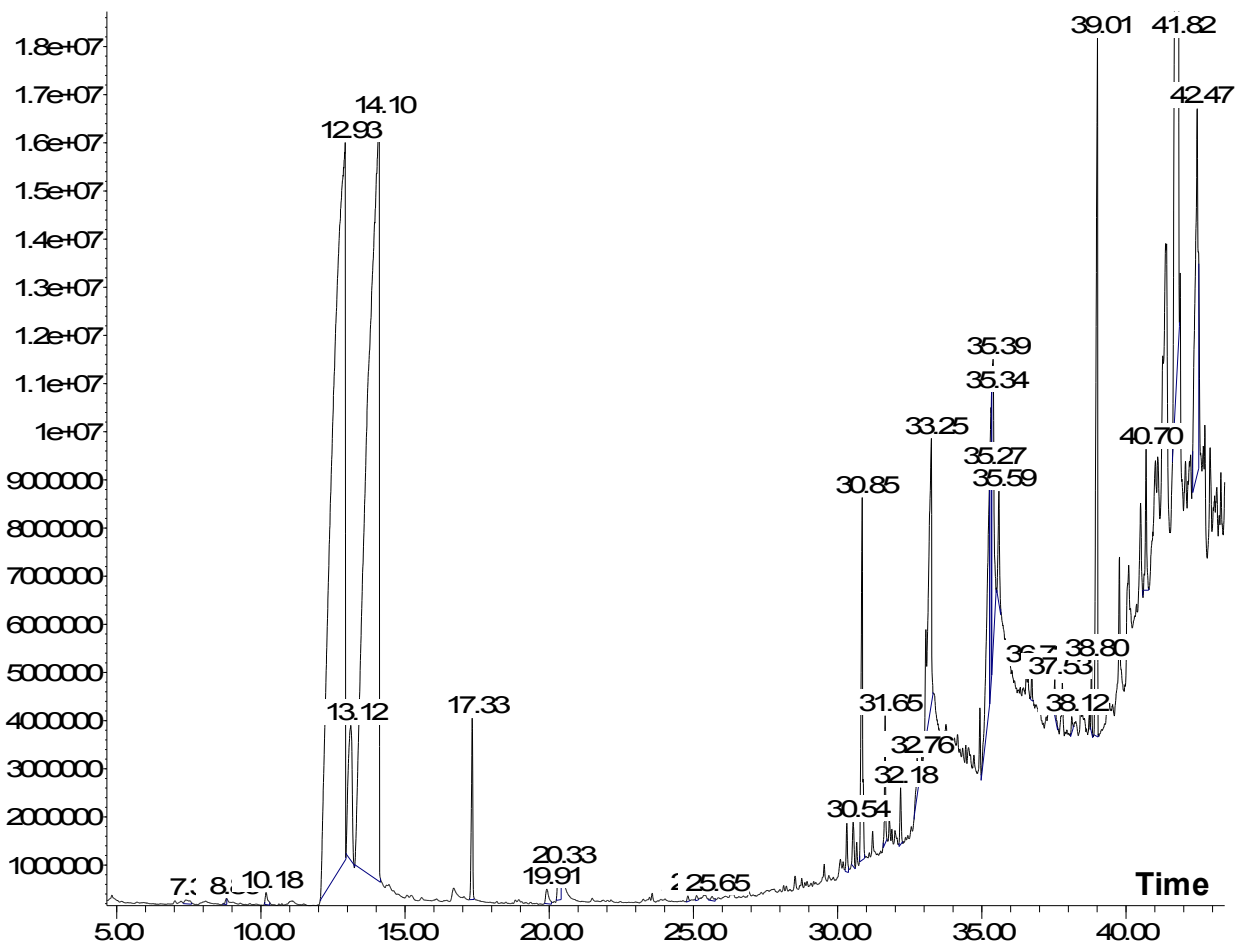

Figure 2. The composition of volatile components of radish 


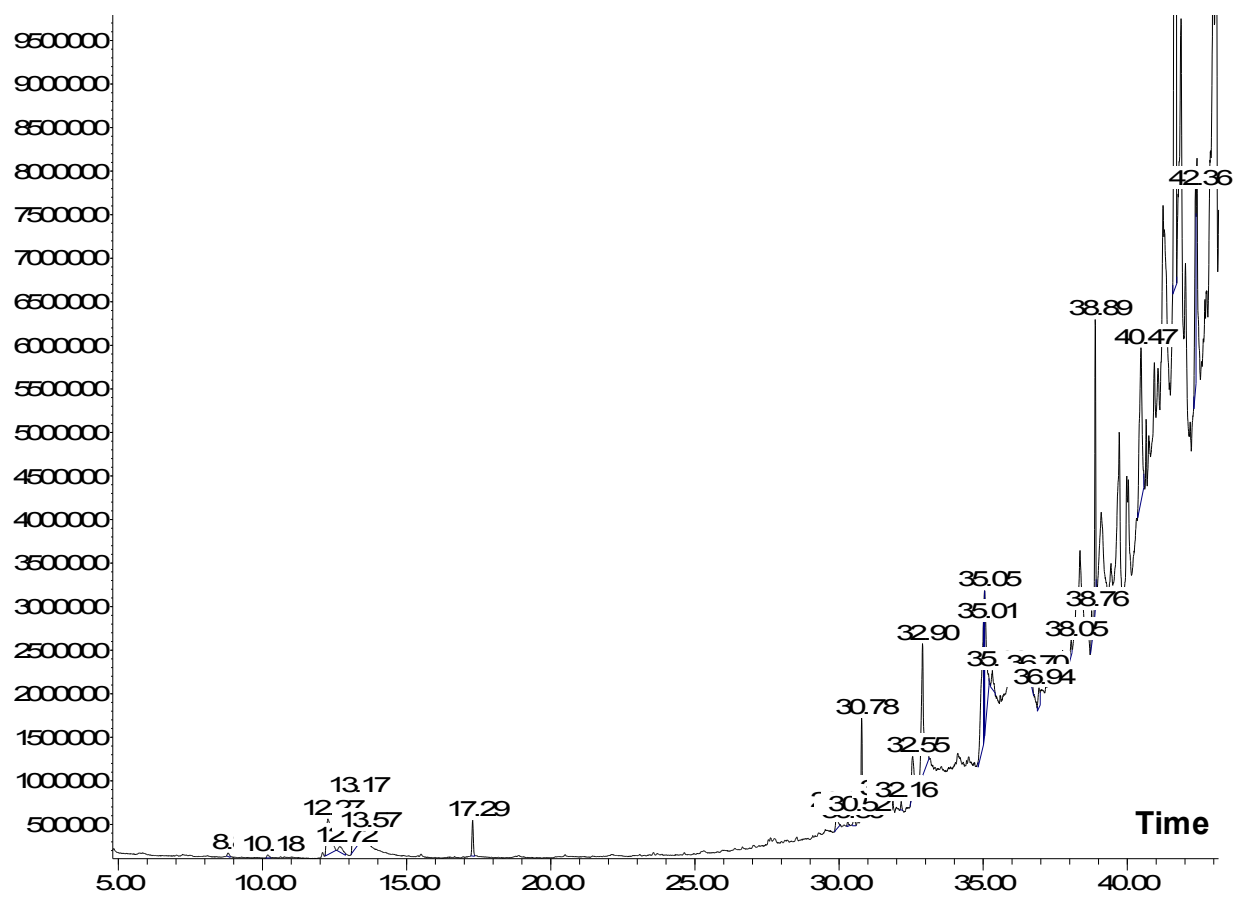

Figure 3. The composition of volatile components of radish Marushka

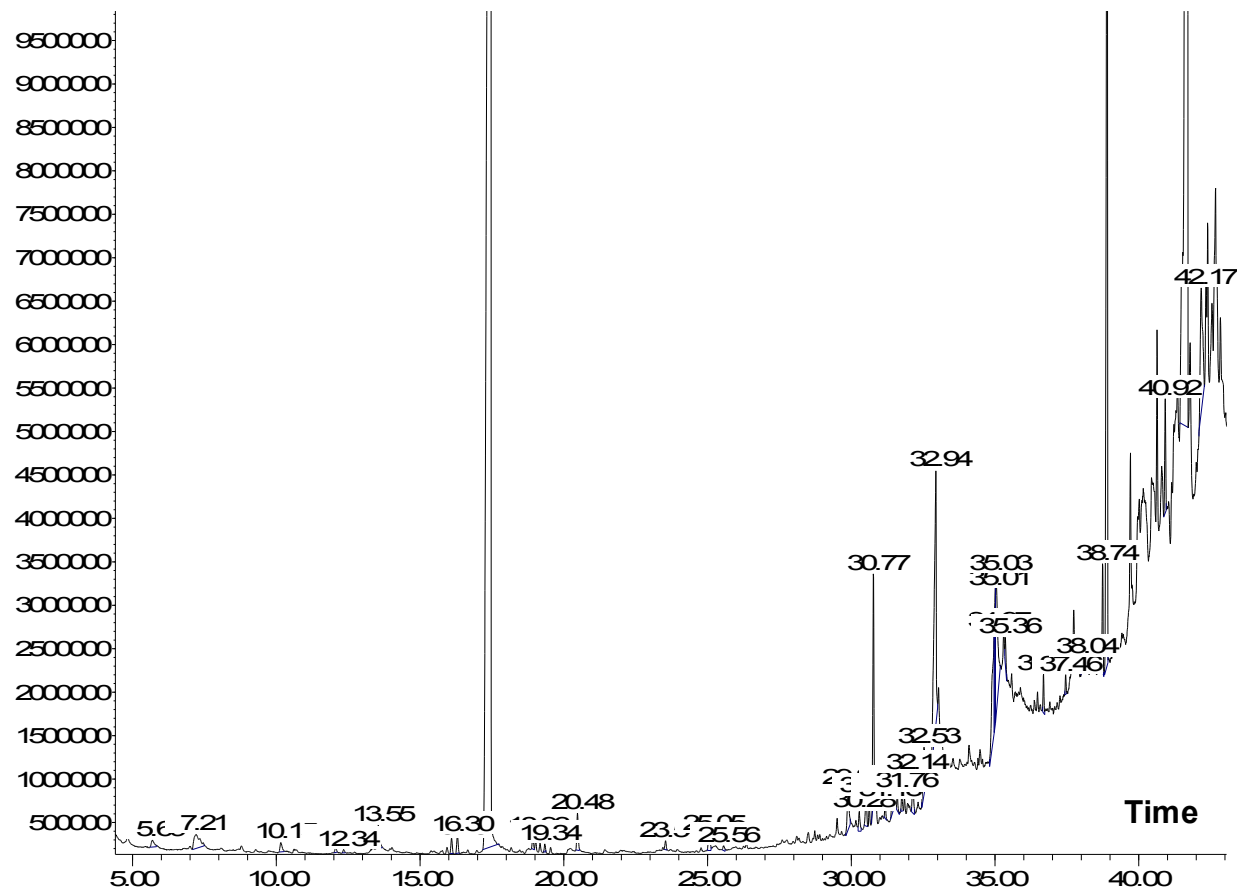

Figure 4. The composition of volatile components of radish Lebidka 


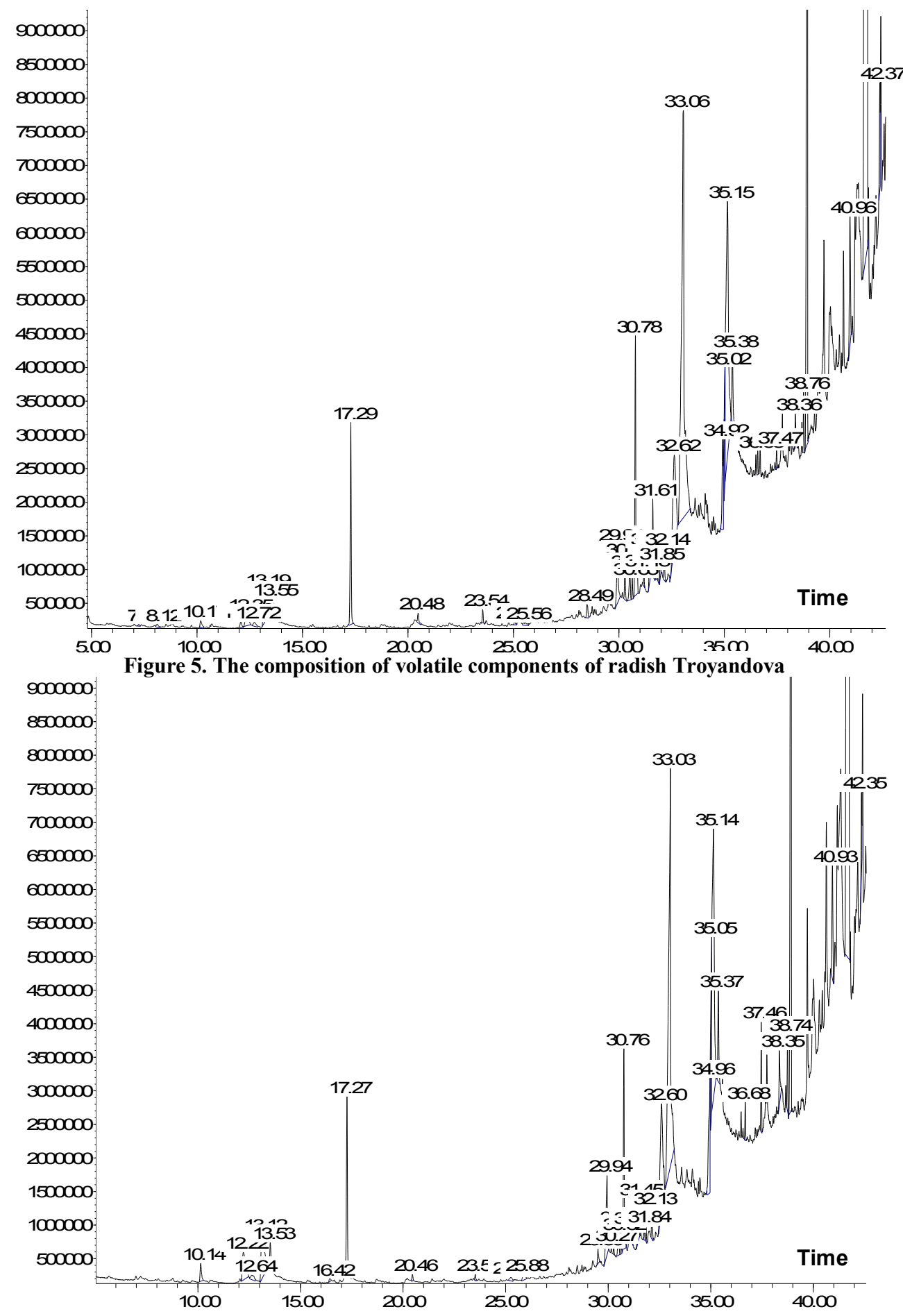

Figure 6. The composition of volatile components of radish Sertse drakona 


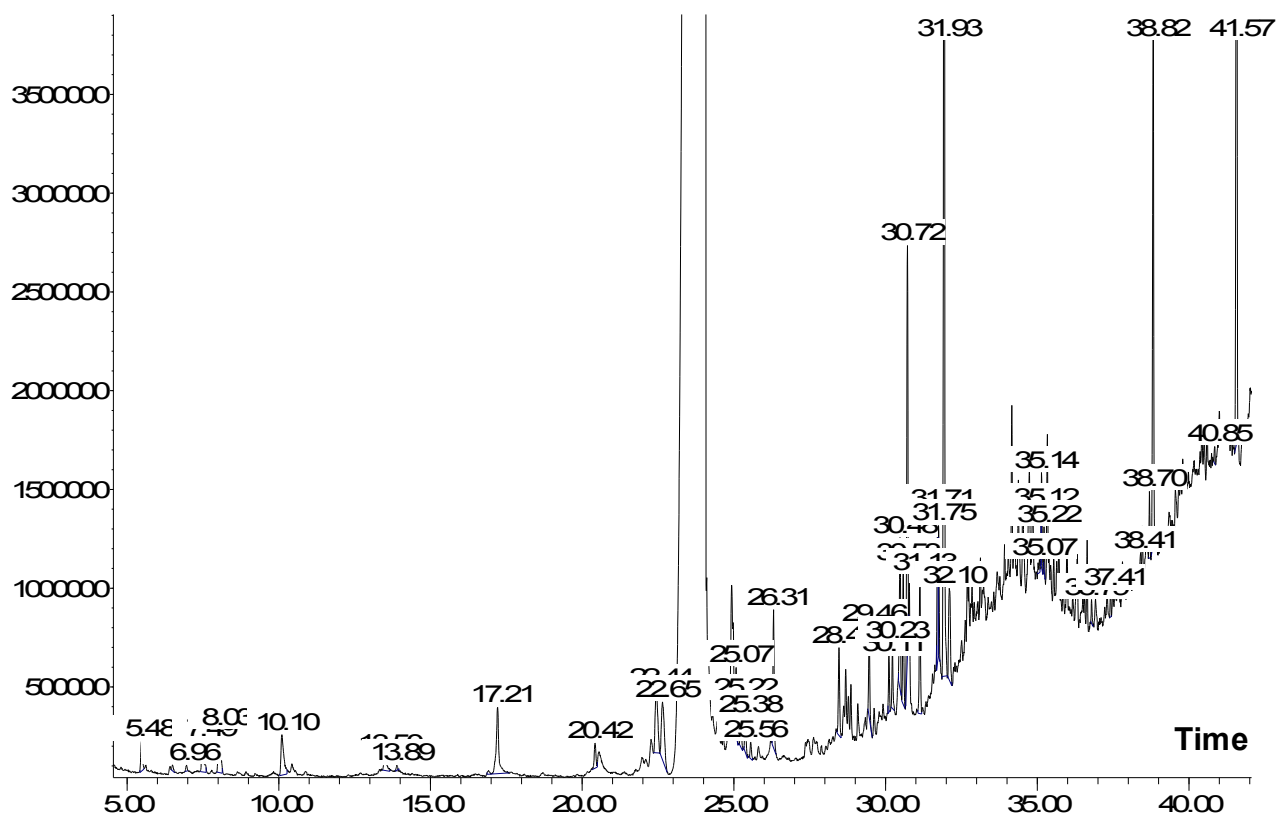

Figure 7. The composition of volatile components of radish Margelan

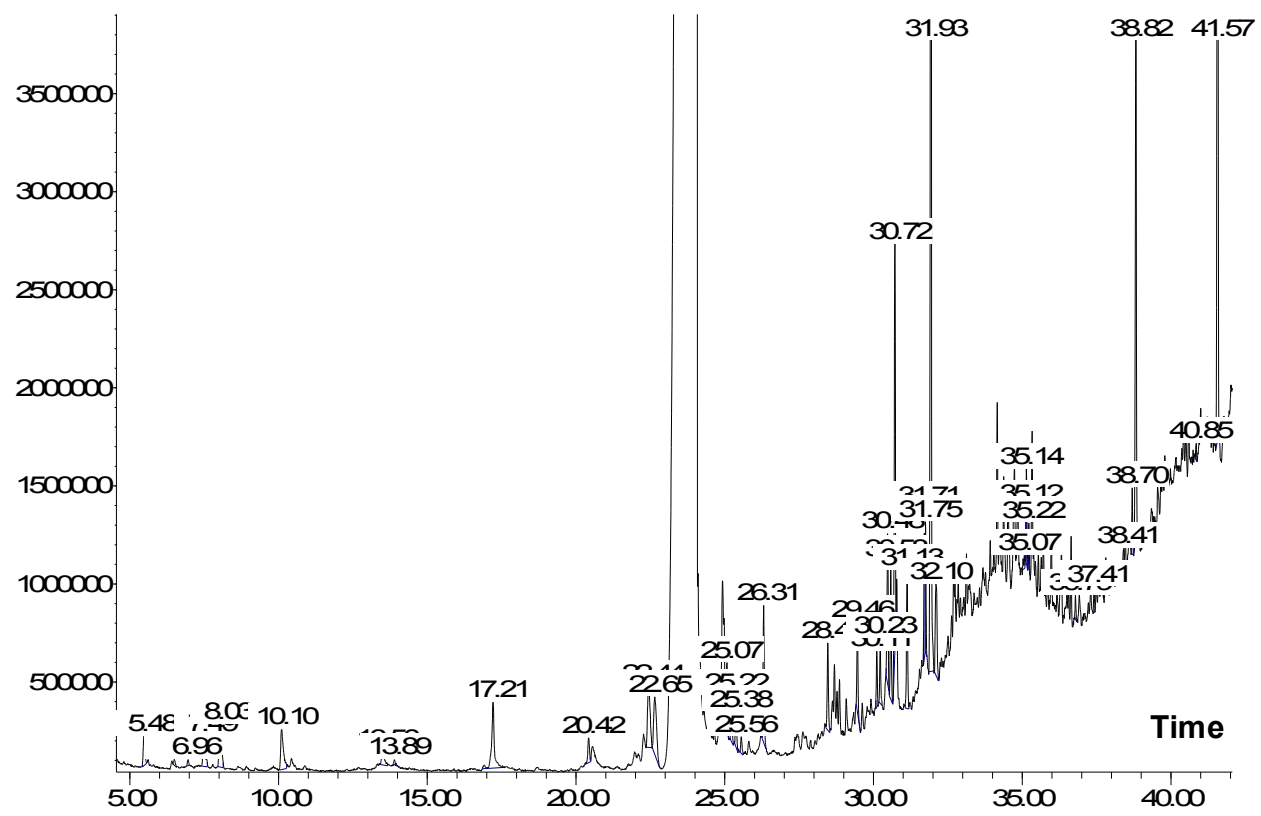

Figure 8. The composition of volatile components of radish Daikon 
Table 1

Comparison component composition of volatile fraction of various varieties radish roots

\begin{tabular}{|c|c|c|c|c|c|c|c|c|}
\hline Component & \multicolumn{8}{|c|}{ Number of economically botanical varieties $\mathbf{m g}$ / kg } \\
\hline 1 & 2 & 3 & 4 & 5 & 6 & 7 & 8 & 9 \\
\hline \multicolumn{9}{|c|}{ Aldehydes } \\
\hline Dekanal & 0,95 & & 4,20 & 0,11 & 1,56 & 2,66 & 1,16 & 0,41 \\
\hline Dodekanal & - & - & - & 0,06 & - & - & - & \\
\hline Tetradekanal & - & - & - & - & 1,24 & - & - & 7,18 \\
\hline Hexadec-7,11-dienal & - & - & - & - & - & 0,88 & 0,81 & - \\
\hline \multicolumn{9}{|c|}{ Ethers } \\
\hline Diisobutylphthalate (3) & 7,75 & 31,35 & 32,50 & 0,61 & 16,99 & 13,77 & 22,54 & 30,45 \\
\hline Dibutylphthalate (3) & - & 3,97 & 2,49 & 0,14 & - & 2,38 & 0,83 & 10,61 \\
\hline 1-Cyano-4, epityopentan & 3,33 & 519,82 & 53,41 & 0,02 & 2,29 & 7,44 & - & 2,54 \\
\hline $\begin{array}{c}\text { 1- Cyano -4,5- epityopentan } \\
\text { (isomer) }\end{array}$ & 8,25 & 508,19 & 84,15 & 0,01 & 8,16 & 11,99 & - & - \\
\hline $\begin{array}{l}\text { 5-(methylthyo) } \\
\text { Pentanenitrile }\end{array}$ & - & 29,90 & 8,10 & - & 0,78 & 1,30 & - & - \\
\hline $\begin{array}{c}\text { 4- Methylthyo-3- } \\
\text { butenylisothiocyanate }\end{array}$ & - & 2,51 & - & - & - & - & - & - \\
\hline
\end{tabular}


Table 1 (Continuation)

\begin{tabular}{|c|c|c|c|c|c|c|c|c|}
\hline \multirow[b]{3}{*}{ Component } & \multirow{2}{*}{\multicolumn{8}{|c|}{ Number of economically botanical varieties mg / kg }} \\
\hline & & & & & & & & \\
\hline & $\begin{array}{r}\text { Black } \\
\text { radish }\end{array}$ & $\begin{array}{l}\text { White } \\
\text { radish }\end{array}$ & Marushka & Lebidka & Troyandova & $\begin{array}{c}\text { Sertse } \\
\text { drakona }\end{array}$ & $\begin{array}{c}\text { Margelan } \\
\text { radish }\end{array}$ & Daikon \\
\hline 1 & 2 & 3 & 4 & 5 & 6 & 7 & 8 & 9 \\
\hline \multicolumn{9}{|c|}{ Alcohols aliphatic } \\
\hline Docosanol & - & - & - & 0,03 & 0,81 & 0,48 & - & - \\
\hline \multicolumn{9}{|c|}{ Alcohols cyclic } \\
\hline Ledol & 0,32 & 0,76 & & 0,02 & 0,70 & 1,19 & - & - \\
\hline \multicolumn{9}{|c|}{ Terpenes and their derivatives } \\
\hline$\alpha$-Pinene & 0,17 & - & - & 0,49 & - & - & - & 4,02 \\
\hline Limonene & 0,32 & 0,57 & 2,38 & - & 0,51 & - & - & 5,71 \\
\hline Nerolidol & 1,60 & 0,48 & - & 0,07 & 0,34 & 0,73 & - & 3,11 \\
\hline$\beta$-Myrcen & 0,05 & - & - & - & - & - & - & 0,60 \\
\hline$\delta$-Karen & 0,17 & 1,15 & - & 0,20 & 0,18 & - & - & 4,31 \\
\hline Squalene & 80,75 & 182,53 & 409,90 & 13,04 & 328,21 & 332,84 & 381,19 & 70,11 \\
\hline \multicolumn{9}{|c|}{ Organic acids } \\
\hline Myristic & 2,36 & - & 11,04 & 0,19 & 5,83 & 8,91 & 8,53 & 7,36 \\
\hline Pentadecanoic & - & - & - & 0,09 & 2,31 & 4,29 & - & - \\
\hline Lauric & - & - & - & 0,02 & - & - & - & - \\
\hline Palmitoleic & 4,12 & 5,44 & 27,28 & 0,29 & 19,23 & 22,89 & 8,39 & - \\
\hline Palmitic & 22,19 & 50,01 & 104,59 & 1,35 & 78,11 & 69,28 & 36,39 & - \\
\hline Linoleic & 22,76 & 36,45 & 86,91 & 0,55 & 7,39 & 11,36 & 3,71 & 1,04 \\
\hline Linolenic & 1,86 & 26,85 & 43,89 & 0,28 & 4,65 & 13,14 & 1,06 & 0,83 \\
\hline Oleic & 1,83 & 34,79 & 76,23 & 0,71 & 45,50 & 44,89 & 9,81 & 4,86 \\
\hline Stearin & 0,54 & 8,88 & 10,76 & 0,07 & 4,90 & 6,88 & 1,19 & 1,82 \\
\hline $\begin{array}{c}11- \\
\text { Cyclopentylundecanoic }\end{array}$ & 0,89 & - & - & - & - & - & - & - \\
\hline
\end{tabular}


Table 1 (Continuation)

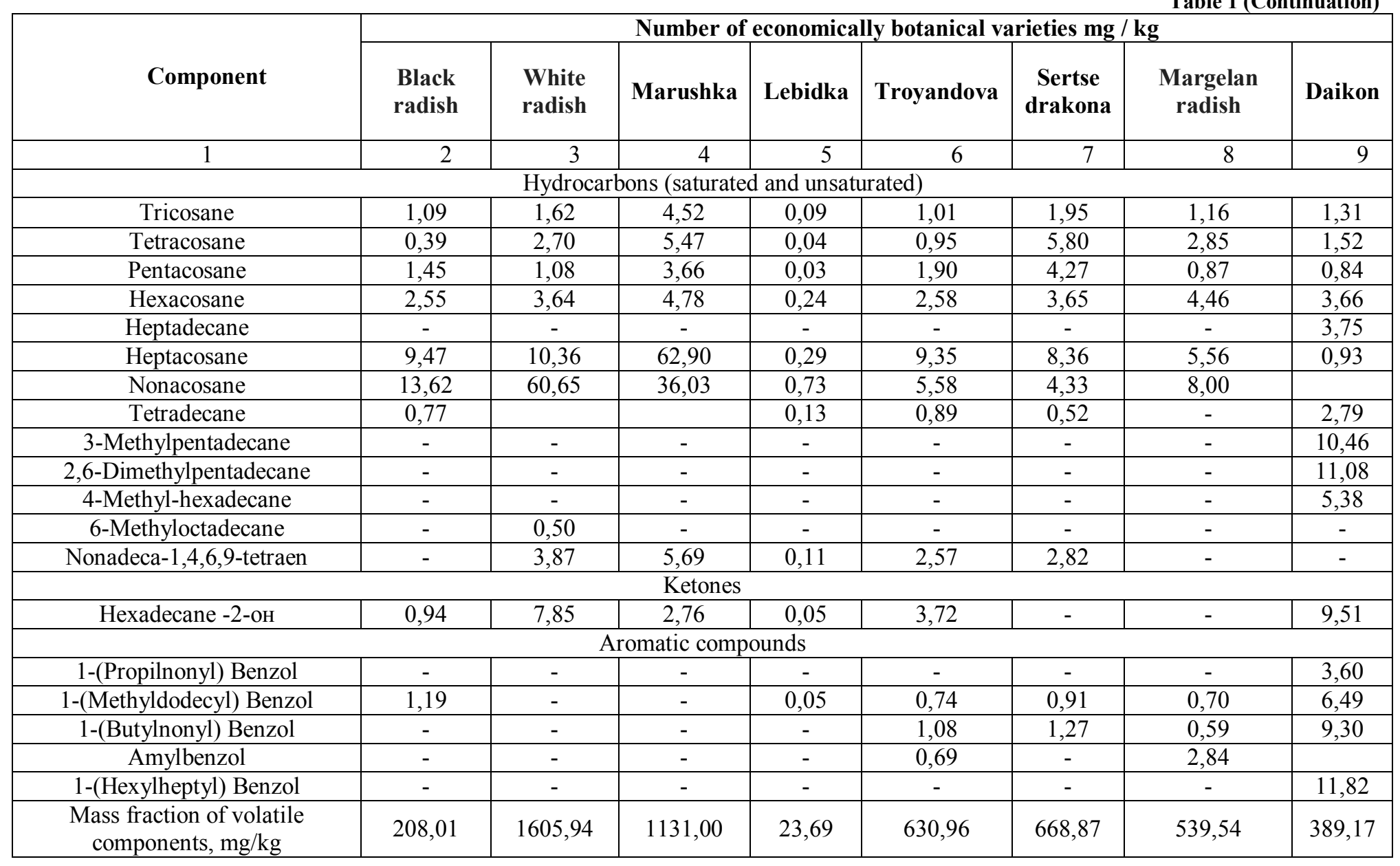


It is reasonable to consider in detail the classes of chemical compounds which are identified in various varieties of radish for understanding the impact of each substance on the formation of biological value and taste, aromatic properties.

Radish aroma forming components include aldehydes [9]: dekanal has strong aldehyde smell and during the dilution its smell has citrus, floral notes (all experimental varieties of radish contain dekanal, except variety White radish); nonal has strong, fatty, muscat smell (all varieties of radish); pentadekanal has strong aldehyde smell (all varieties of radish); dodekanal has strong smell with floral and grass notes (only variety Lebidka); tetradekanal has soft, fatty smell with notes of toffee (varieties Troyandova and daikon); hexadek-7,11dienal has soft, floral-aldehyde smell with grass notes (varieties Sertse drakona and Margelan radish).

Ethers of complex aromatic acids in the investigated samples of radish are presented by the following substances: diisobutylphthalate in an amount of 0,61 (Lebidka) to 31,35 $\mathrm{mg} / \mathrm{kg}$ (White radish) and dioctylphthalate from 3,46 (Lebidka) to 74,72 $\mathrm{mg} / \mathrm{kg}$ (Sertse drakona); the concentration of dibutylphthalate is from $0,14 \mathrm{mg} / \mathrm{kg}$ (Lebidka) to 10,61 (daikon), varieties Black radish and Troyandova don't contain this component. In addition the variety of radish Sertse drakona contains ether methylmyristate in amount of $0,5 \mathrm{mg} / \mathrm{kg}$, daikon contains methylpalmitate $(90,74 \mathrm{mg} / \mathrm{kg})$. Identified ethers are characterized by relatively pleasant expressionless fruity smell, it to a certain extent promotes the balancing of radish flavor [10].

Volatile fractions of radish in the composition have large numbers of sulfur-containing compounds, namely, 1-cyano-4,5-epitiopentan, 1-cyano-4,5- epityopentan (isomer), 5-(me x xzzz thylthyo) pentanenitrile, 4-methylthyo-3-butenylisothiocyanate, which have strong, unpleasant smell. It is known that essential oils with sulfur should be used with great caution and under strong dilution. However, the concentration of these substances in roots is non-toxic. The radish of variety White radish has the highest total number of sulfurcontaining compounds $-1060,42 \mathrm{mg} / \mathrm{kg}$, and the radish of variety Lebidka has the smallest number of sulfur-containing compounds $-0,03 \mathrm{mg} / \mathrm{kg}$, the radish of variety Margelan radish hasn't sulfur-containing compounds in its composition.

Aliphatic and cyclic alcohols are present in radish roots in the small amount but they have high antiviral and antimicrobial properties [11]. Docosanol is identified in varieties Lebidka, Troyandova, Sertse drakona and ledol is identified in varieties Black radish, White radish, Lebidka, Troyandova and Sertse drakona.

Terpenes are the main components of radish essential oils; they provide spicy taste and specific flavor. In addition, the presence of terpenes allows naturally without the use of chemicals to keep pests from radish. The composition of radish varieties Black radish and daikon includes all identified terpenes ( $\alpha$-pinene, limonene, nerolidol, $\beta$-Myrcen, $\delta$-Karen, squalene), the total mass of them is 83,06 and $87,86 \mathrm{mg} / \mathrm{kg}$ respectively. The varieties of radish White radish and Troyandova contain four representatives of the class of terpenes (limonene, nerolidol, $\delta$-Karen and squalene), and the sample of variety Lebidka contains $\alpha$ pinene, nerolidol, $\delta$-Karen, squalene. Limonene and squalene are contained in the radish of variety Marushka and the radish of variety Sertse drakona contains nerolidol and squalene. The radish of variety Margelan radish only contains squalene.

Radish terpenes have substantial differences in chemical properties. So, $\alpha$-pinene is bicyclic terpene, which is a colorless, volatile liquid with characteristic "pine» smell; limonene is monocyclic terpene, has citrus flavour; nerolidol is colorless oily liquid with faint floral flavour; $\beta$-Myrcen is oily liquid with pleasant spicy flavor; $\delta$-Karen is colorless liquid with pleasant sweet smell 
The presence in radish roots of squalene (acyclic polyunsaturated liquid hydrocarbon, colorless and odorless, soluble in many organic solvents) is extremely interesting, because it is believed that the main its source is the only shark liver (35\%) and olive and rice oils (to $0,8 \%$ ) [12].

It is ascertained that the concentration of squalene in different varieties of radish has significant divergence from $13,04 \mathrm{mg} / \mathrm{kg}$ (Lebidka) to $409,9 \mathrm{mg} / \mathrm{kg}$ (Marushka). Its chemical formula is quite unstable because of the lack of hydrogen, which is filled with reaction with water, during this reaction the oxygen releases and this terpene saturates body tissues, and it helps to eliminate free radicals. It provides squalene with certain antioxidant properties. In addition, it is an intermediate substance in the biological synthesis of steroids, including cholesterol (by the use of lanosterol), and it is involved in metabolism [13].

Fatty acids, including essential - linoleic and linolenic were found during the study volatile components of radish also were found. All varieties contain in their composition linoleic acid $(0,55 \ldots 86,91 \mathrm{mg} / \mathrm{kg})$, linolenic acid $(0,28 \ldots 43,89 \mathrm{mg} / \mathrm{kg})$, oleic acid $(0,71 \ldots 76,23 \mathrm{mg} / \mathrm{kg})$, stearic acid $(0,54 \ldots 10,76 \mathrm{mg} / \mathrm{kg})$. Myristic fatty acids are contained in the range of $0,19 \ldots 11,04 \mathrm{mg} / \mathrm{kg}$ in all samples of radish except White radish. Palmitic and palmitooleic acids are contained in all varieties of radish $(1,35 \ldots 104,59 \mathrm{mg} / \mathrm{kg}$ and $0,29 \ldots 27,28 \mathrm{mg} / \mathrm{kg}$, respectively), but daikon doesn't contain these acids. It should be noted that the presence of palmitooleic acid, which has high antimicrobial action, in vegetable products with low fat content is rarity, because basically its sources are the fat of marine animals $(15 \ldots 20 \%)$, chicken egg yolk $(5 \%)$ macadamia oils $(6 \ldots 12 \%)$, avocados $(5 \ldots 10 \%)$, olive oil $(9 \%)[14]$.

Varieties of radish Lebidka, Troyandova and Sertse drakona also contain such organic acid as pentadecanoic acid in an amount of $0,09 \ldots 4,29 \mathrm{mg} / \mathrm{kg}$. In addition, the variety of radish Black radish contains 11 -cyclopentylundecanoic acid $(0,89 \mathrm{mg} / \mathrm{kg})$ and lauric acid is contained in radish Lebidka $(0,02 \mathrm{mg} / \mathrm{kg})$. Notably, that radish Marushka has record high concentrations of organic acids, while variety of radish Lebidka is characterized by low content of these substances.

Saturated hydrocarbons (tricosane, tetracosane, pentacosane, hexacosane, heptadecane, nonadecane, heptacosane nonacosane, tetradecane) and unsaturated hydrocarbons (3methylpentadecane, 2,6-dimethylpentadecane, 4-methyl-hexadecane, 6-methyloctadecane, nonadeca-1,4,6,9-tetraen) are identified in radish roots, they are characterized by more or less intense smell of petrochemical products. Tricosane in amount of $0,09 \ldots 1,95 \mathrm{mg} / \mathrm{kg}$, tetracosane $-0,04 \ldots 5,8 \mathrm{mg} / \mathrm{kg}$, pentacosane $-0,03 \ldots 4,27 \mathrm{mg} / \mathrm{kg}$, hexacosane $-0,93 \ldots 62,80$ $\mathrm{mg} / \mathrm{kg}$ are common for all varieties of radish. 3-methylpentadecane, 2,6dimethylpentadecane, 4-methyl-hexadecane, heptadecane, nonadecane are specific and identified only in daikon, mass fraction of this substances is dominated in daikon. Unsaturated hydrocarbon 6-methyloctadecane is identified only in the sample of radish Marushka $(0,5 \mathrm{mg} / \mathrm{kg})$. It should be noted that this variety contains the largest amount of hydrocarbons $(123,05 \mathrm{mg} / \mathrm{kg})$ and the sample Lebidka contains the smallest amount of hydrocarbons $(1,66 \mathrm{mh} / \mathrm{kg})$.

The representative of the ketones class - hexadecane -2-oH also is identified, the mass fraction of which is from $0,05 \mathrm{mg} / \mathrm{kg}$ (Lebidka) to $9,51 \mathrm{mg} / \mathrm{kg}$ (daikon). In addition, arenas (aromatic compounds) are similar in chemical structure to the hydrocarbons are identified as the study result; they have sweet smell and are not inclined to joining or oxidation reactions that leads to disruption of aromaticity [303]. So, samples of Black radish and Marushka contain only one representative of this group of chemicals - 1-(methyldodecyl) benzol; sample of Sertse drakona contains two arenas (1-(methyldodecyl) benzol and 1(butylnonyl) benzol), varieties Lebidka and Margelan radish contain amylbenzol, 1- 
(methyldodecyl) benzol and 1-(butylnonyl) benzol; daikon contain the largest amount of arenas (31,21 mg/kg): 1-(propilnonyl) benzol, 1-(butylnonyl) benzol, 1-(Hexylheptyl) Benzol and 1-(methyldodecyl) benzol.

\section{Conclusions}

Thus, complex volatile composition are isolated from various economic and botanical varieties of radish roots are presented by such chemicals as hydrocarbons, sulfur-containing substances, organic acids, aldehydes, ethers, ketones, terpenes, alcohols and arenas, total mass fraction of which is in the range of $23,69 \mathrm{mg} / \mathrm{kg}$ (Lebidka) to $1605,94 \mathrm{mg} / \mathrm{kg}$ (White radish). From 26 to 40 compounds are identified, most of which are specific for each sample of variety, but 14 compounds are common to all varieties of radish. They are nonanal, pentadekanal, dioctylphthalate, diisobutylphthalate, squalene, linoleic acid, linolenic acid, oleic acid, stearic acid, tricosane, tetracosane, pentacosane, hexacosane and heptacosane. It is established that the various component composition of radish volatile substances determines specificity and intensity of flavor, has significant impact on taste properties and makes antibacterial activity against gram-positive and gram-negative microorganisms. The results are major quality criteria for the distribution of varieties of radish according to tendencies of use. Varieties of roots White radish and Marushka have high total content of volatiles that causes intense specific smell, spicy taste and strong bactericidal effect, and varieties (Lebidka, Black radish, daikon, Margelan radish , Troyandova, Sertse drakona) with minimum and average number of essential oils have less intensity smell and are suitable for industrial processing.

\section{References}

1. Gilani A.H., Ghayur M.N. (2004), Pharmacological basis for the gut stimulatory activity of Raphanus sativus leaves, J. Ethnopharmacol, 95, pp. 169-172.

2. Terras F.R., Schoofs H.M., DeBolle M.F., Van Leuven F., Rees S.B., Vanderleyden J., Cammue B.P., Broekaert W.F. (1992), Analysis of two novel classes of plant antifungal proteins from Radish (Raphanus sativus L.) seeds, J. Biol. Chem, 267, pp. 15301-15309.

3. Friis P., Kjaer A. (1966) 4-Methylthio-3-butenyl-isothiocyanate, the pungent principle of radish root, Acta Chem. Scand, 20, pp. 698-705.

4. Jones L.J.L., Thorpe J.P., Wallis G.P. (1982), Genetic divergence in four species of the genus Raphanus: Implications for the ancestry of the domestic radish R. sativus, $J$. Linnean Society, 18(1), pp. 35-48.

5. Suleiman A. and Maryam H.B. (2005), Volatile Constituents of Raphanus sativus L. var. niger Seeds, J. Essential Oil Res., 17(4), pp. 440-441.

6. Iliana Kostova, Dimitar Dimitrov, Mihaela Ivanova, Radka Vlaseva, Stanka Damyanova, Nastya Ivanova, Albena Stoyanova, Oleksii Gubenia (2014), Studying the possibilities of using of essential oils in dairy products. 2. Dill (Anethum Graveolens), Ukrainian Food Journal, 3(4), pp. 516-523.

7. Teodora Atanasova, Miroslava Kakalova, Lyubomir Stefanof, Maya Petkova, Albena Stoyanova, Stanka Damyanova, Mykola Desyk (2016), Chemical composition of 
essential oil from Rosa Damascena mill., growing in new region of Bulgaria, Ukrainian Food Journal, 5(3), pp. 492-498.

8. Chernogorod L.B., Vinogradov B.A. (2006), Essential oils of some species of the genus Achillea L., containing fragranol, Plant Resources, 42(2), pp. 61-68.

9. Kohlpaintner C., Schulte M., Falbe J., Lappe P., Weber J., Frey G. D. (2013), Aldehydes, Araliphatic, Ullmann's Encyclopedia of Industrial Chemistry, Wiley, DOI:10.1002/14356007.m01_m03.pub2.

10. Jonathan Clayden (2008), Science of Synthesis: Houben-Weyl Methods of Molecular Transformations, Georg Thieme Verlag.

11. Kulkarni L and Sohonie K. (1956), Non protein nitrogen in vegetables, Indian J. Med. Res., 44, pp. 511-518.

12. Eberhard Breitmaier. Terpens, WILEY-VCH Verlag Gmbh \& Co. KGaA, Weinheim.

13. Sandovala M, Okuhamaa N.N., Angelesam F.M., Melchora V.V., Condezob L.A., Laob J., Millera M.J.S. (2002), Antioxidant activity of the cruciferous vegetable Maca (Lepidium meyenii), Food Chemistry, 79, pp. 207-213.

14. Eskin M NA and Tamir S. (2005), Functional foods and nutraceuticals, Dictionary of Nutraceuticals and Functional Foods, 1, pp. 377-378. 